\title{
Germanium Poisoning: Clinical Symptoms and Renal Damage Caused by Long-term Intake of Germanium
}

\author{
Katsuya Obara, Takao SAITO, Hiroshi SAto, Kei YAMAKAGE****, \\ Takao WATANABE*****, Miho KAKIZAWA*, Tetsuro TSUKAMOTO**, \\ Kazuo KOBAYASHI**, Michio HONGO*** and Kaoru YoshINAGA
}

\begin{abstract}
We report five patients who have taken inorganic germanium preparations over a prolonged period. In all cases, the renal function deteriorated with no proteinuria or hematuria. Histological examination of the kidneys showed widespread tubular degeneration and interstitial fibrosis with minor glomerular abnormalities. Most patients had gastrointestinal symptoms such as vomiting, anorexia and weight loss; one patient had peripheral neuropathy and myopathy. A considerable amount of germanium was detected in the hair or nails of these patients. These cases clearly show that abuse of inorganic germanium compounds can induce renal damage with various extrarenal manifestations.
\end{abstract}

Key words: Intestinal transit, Myopathy, Peripheral neuropathy, Tubulo-interstitial lesions

Germanium $(\mathrm{Ge})$, with an atomic number of 32 , exists as a trace metal in plants and animals. The sources of $\mathrm{Ge}$ are widespread in food and probably in air contaminated by coal smoke (1). Although it is known that Ge has a low toxicity in animals (1), little has been known about its toxicity in man until recently.

In recent years, some Japanese people have habitually taken Ge preparations, of which the major component is inorganic $\mathrm{Ge}$, as a type of elixir to maintain their health or to improve their sense of well-being. Since Nagata et al (2) described a case of acute renal failure with a high level of $\mathrm{Ge}$ accumulation in various tissues in 1985, similar cases with renal failure induced by long-term Ge intake have been reported in Japan (3-5). Here, five patients with renal dysfunction who have taken Ge preparations for a long time, and some of whom had serious extrarenal symptoms are reported.

\section{CASE REPORT}

\section{Case 1}

A 6-year-old girl was admitted to our hospital because of frequent vomiting and muscle weakness with malnutrition in November 1986. Before admission, she had been given a total of $40 \mathrm{~g}$ of an inorganic Ge preparation over the past 18 months to improve her mental retardation.

The urine gave a negative test for protein; the sediment was normal. The blood urea nitrogen was $52 \mathrm{mmol} / \mathrm{l}(146 \mathrm{mg} / \mathrm{dl})$, the serum creatinine, 389 $\mu \mathrm{mol} / 1(4.4 \mathrm{mg} / \mathrm{dl})$ and the serum uric acid, 773 $\mu \mathrm{mol} / \mathrm{l})(13.0 \mathrm{mg} / \mathrm{dl})$. A routine hematological study showed a normochromic normocytic anemia: hemoglobin $4.7 \mathrm{nmol} / 1(7.5 \mathrm{~g} / \mathrm{dl})$, hematocrit 0.21 $(21 \%)$ and red blood cell $2.52 \times 10^{12} / 1$

From Second Department of Internal Medicine, *Department of Pediatrics, **Department of Neurology and ***Third Department of Internal Medicine, Tohoku University School of Medicine, Sendai, ****Department of Internal Medicine, Sendai Municipal Hospital, Sendai and *****Miyagi University of Education, Sendai Received for publication October 30, 1989; Accepted for publication September 17, 1990

Reprint requests should be addressed to Katsuya Obara, MD, The Second.Department of Internal Medicine,

Tohoku University School of Medicine, 1-1 Seiryo-cho, Aoba-ku, Sendai 980, Japan 
$\left(252 \times 10^{4} / \mathrm{mm}^{3}\right)$. The specimen obtained at renal biopsy showed marked tubular degeneration (Fig. 1) and widespread interstitial fibrosis with foci of mononuclear cell infiltration. The glomeruli showed no remarkable changes. Immunofluorescence studies for immunoglobulins and complements revealed no pathological deposition. On electron microscopy, electron dense granules were found in mitochondria of tubular epithelial cells and in lysosomes of fibroblasts.

Although her nutritional state was gradually improved by intravenous hyperalimentation and the blood urea nitrogen fell to about $14 \mathrm{mmol} / \mathrm{l}$ (40 $\mathrm{mg} / \mathrm{dl}$ ), she frequently vomited. Gastroduodenoscopy revealed no abnormal findings. Three months after admission, she died of respiratory failure following an episode of mis-swallowing of vomit.

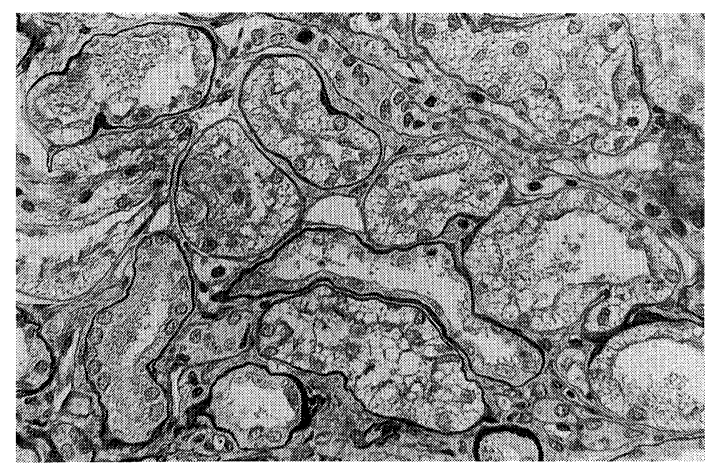

Fig. 1. Light micrograph of kidney in case 1. Tubuli are atrophic and vacuolation of tubular epithelium is seen (PAS stain, $\times 400$, biopsy specimen).

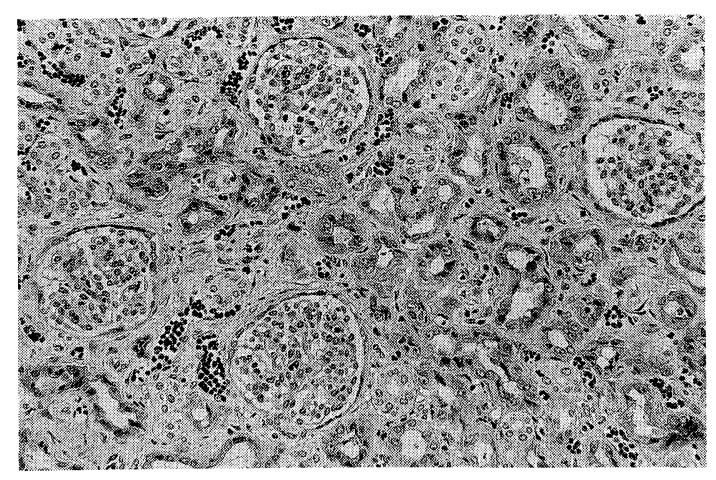

Fig. 2. Light micrograph of kidney in case 1. Extensive tubular atrophy and interstitial fibrosis are seen. No remarkable changes can be found in glomeruli (ElasticaMasson stain, $\times 100$, autopsy specimen).
Autopsy revealed the following: renal histology was essentially the same as that of biopsy, but more remarkable in interstitial fibrosis (Fig. 2). Bone marrow was hypoplastic. Although bronchopneumonia was noted, myocardium, intestine, liver, spleen and lymph nodes showed no marked abnormalities.

\section{Case 2}

A 50-year-old man was referred to our hospital because of frequent vomiting, weight loss and numbness of limbs in February 1987. He had taken 70 $\mathrm{mg}$ of an inorganic Ge preparation daily for the past 26 months (total dose of approximately $55 \mathrm{~g}$ ). Prior to $\mathrm{Ge}$ intake, a health examination showed no abnormalities in his renal function: blood urea nitrogen $4.6 \mathrm{mmol} / 1(13 \mathrm{mg} / \mathrm{dl})$, serum creatinine $97 \mu \mathrm{mol} / 1(1.1 \mathrm{mg} / \mathrm{dl})$, and creatinine clearance 103 $\mathrm{ml} / \mathrm{min}$. Seven months before the hospitalization, he experienced general fatigue. Two months later, he experienced numbness in limbs, and then lost 21 $\mathrm{kg}$ due to nausea and vomiting.

On admission, neurological examination revealed diminished superficial sensation of his distal limbs and diminished tendon reflexes in his legs. Urine protein was neglible; the sediment was normal. His renal function was severely deteriorated: blood urea nitrogen $23 \mathrm{mmol} / \mathrm{l}(64 \mathrm{mg} / \mathrm{dl})$, serum creatinine 548 $\mu \mathrm{mol} / 1$ ( $6.2 \mathrm{mg} / \mathrm{dl})$, serum uric acid $779 \mu \mathrm{mol} / 1$ (13.1 $\mathrm{mg} / \mathrm{dl}$ ), and creatinine clearance $11 \mathrm{ml} / \mathrm{min}$. The serum creatine kinase was 3,764 U/l (isozyme: MM $99 \%$, MB 1\%). Electromyogram showed myogenic and neurogenic changes. Motor nerve conduction velocity was almost normal, while sensory nerve action potential was not evoked at the median, ulnar or sural nerves. A biopsy specimen taken from the sural nerve showed a decrease in myelinated fibers, particularly in large myelinated fibers, and a large number of myelin ovoids indicating severe axonal degeneration (Fig. 3). During the two months following admission, a normochromic normocytic anemia developed: hemoglobin $5.9 \mathrm{nmol} / 1$ (9.3 $\mathrm{g} / \mathrm{dl})$, hematocrit $0.27(27 \%)$ and red blood cell count $3.01 \times 10^{12} / 1 \quad\left(301 \times 10^{4} / \mathrm{mm}^{3}\right)$. The bone marrow biopsy specimen showed hypoplasia.

The serum creatine kinase level was decreased after cessation of Ge intake and returned to normal two months later, but his paresthesia persisted. $\mathrm{He}$ frequently vomited even with administration of 


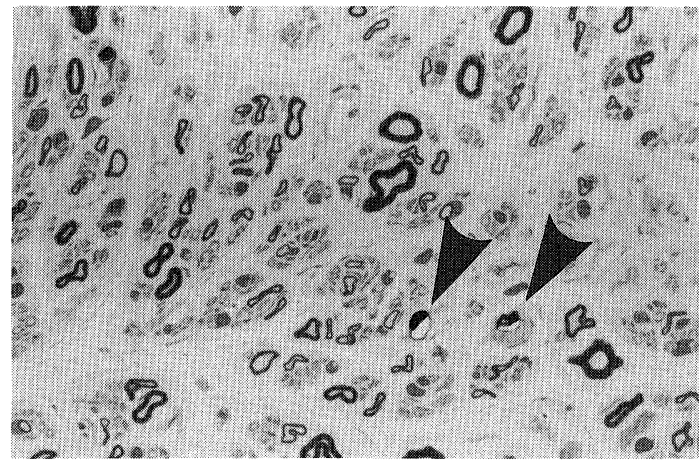

Fig. 3. Light micrograph of sural nerve biopsy specimen in case 2 . Large myelinated fibers decrease and myelin ovoids (arrows) are seen (toluidine blue stain, $\times 300$ ).

strong antiemetic drugs. Gastroduodenoscopy showed no particular abnormalities. The examination of intestinal transit using radio-opaque markers (6) revealed a delay in gastrointestinal transit, particularly in gastric emptying. He still had difficulty in eating food one yr after cessation of Ge intake.

\section{Case 3}

A 66-year-old man was referred to our hospital in May 1987 because of chronic renal failure. At the age of 22, he had Weil's disease. However, the details were unknown. From December 1986 to February 1987, he had taken an inorganic Ge preparation (total dose of about $20 \mathrm{~g}$ ). In December 1986, his renal function had already deteriorated: blood urea nitrogen $14 \mathrm{mmol} / \mathrm{l}(39 \mathrm{mg} / \mathrm{dl})$; serum creatinine $203 \mu \mathrm{mol} / 1$ ( $2.3 \mathrm{mg} / \mathrm{dl})$. In February 1987, the red blood cell count was $3.55 \times 10^{12} / 1$ $\left(355 \times 10^{4} / \mathrm{mm}^{3}\right)$ and the hemoglobin $7.0 \mathrm{nmol} / 1$ $(11.3 \mathrm{~g} / \mathrm{dl})$. Although gastrointestinal examinations showed no abnormalities except for colon polyps, he had lassitude and anorexia with weight loss of $5 \mathrm{~kg}$ over the following two months.

On admission, the urine was normal. The blood urea nitrogen was $24 \mathrm{mmol} / \mathrm{l}(68 \mathrm{mg} / \mathrm{dl})$, the serum creatinine, $239 \mu \mathrm{mol} / 1(2.7 \mathrm{mg} / \mathrm{dl})$ and the serum uric acid, $660 \mu \mathrm{mol} / 1(11.1 \mathrm{mg} / \mathrm{dl})$. A routine hematological study revealed: hemoglobin 5.6 $\mathrm{nmol} / \mathrm{l}(9.1 \mathrm{~g} / \mathrm{dl})$; hematocrit $0.26(26 \%)$; red blood cell count $2.82 \times 10^{12} / 1\left(282 \times 10^{4} / \mathrm{mm}^{3}\right)$.

Case 4

A 73-year-old man was admitted to our hospital for the treatment of cerebral infarction with diabetes mellitus and chronic renal insufficiency in September 1988. When glycosuria was first found in December 1983, his renal function was normal: blood urea nitrogen $6 \mathrm{mmol} / 1(17 \mathrm{mg} / \mathrm{dl})$; serum creatinine 80 $\mu \mathrm{mol} / \mathrm{l}(0.9 \mathrm{mg} / \mathrm{dl})$. He believed that an inorganic Ge preparation was beneficial for diabetes mellitus, and had taken it from April 1984 to March 1986. Although his diabetes mellitus was well controlled with diet therapy and his urinalysis was normal during the $\mathrm{Ge}$ intake, lassitude and loss of appetite with progressive renal dysfunction developed.

On admission, the urine gave a negative test for protein; the sediment was normal. The blood urea nitrogen was $12 \mathrm{mmol} / 1(35 \mathrm{mg} / \mathrm{dl})$ and serum creatinine, $159 \mu \mathrm{mol} / 1(1.8 \mathrm{mg} / \mathrm{dl})$.

Case 5

A 46-year-old woman had taken an inorganic $\mathrm{Ge}$ preparation from September 1985 to April 1986 (total dose of about $16 \mathrm{~g}$ ). In 1984, a health examination in a private clinic showed blood urea nitrogen $3 \mathrm{mmol} / \mathrm{l}(9 \mathrm{mg} / \mathrm{dl})$, serum creatinine, $53 \mathrm{~mol} / 1$ (0.6 $\mathrm{mg} / \mathrm{dl})$ and serum uric acid, $226 \mu \mathrm{mol} / 1$ ( $3.8 \mathrm{mg} / \mathrm{dl})$. The urine was normal. Throughout the year of 1986 , she had frequent vomiting and a weight loss of 8 kg. However, gastrointestinal examinations showed no particular abnormalities. Her frequent vomiting improved without any treatment in the spring of 1987.

In December 1988, she visited our hospital as she had read of Ge-induced nephropathy reported in a newspaper. The urine was normal. The blood urea nitrogen was $15 \mathrm{mmol} / \mathrm{l}(43 \mathrm{mg} / \mathrm{dl})$, serum creatinine $168 \mu \mathrm{mol} / 1(1.9 \mathrm{mg} / \mathrm{dl})$ and serum uric acid 529 $\mu \mathrm{mol} / 1(8.9 \mathrm{mg} / \mathrm{dl})$. The kidney biopsy specimen showed widespread tubular atrophy and diffuse interstitial fibrosis without remarkable changes in glomeruli. There was no deposition of immunoglobulin or complement.

\section{MEASUREMENT OF GERMANIUM}

\section{Methods}

Hair samples were taken by clipping with stainless steel scissors as close as possible to the scalp from several occipital sites, and then washed in acetone and water (7). Finger nails and toe nails were washed with detergents of $0.4 \%$ polyoxyethylene glycol lauryl ether and rinsed with redistilled water (8). The hair and nail samples were freeze-dried for $24 \mathrm{~h}$ to 
obtain the weight before the ashing procedure. Twenty-four $h$ urine samples were stored at $-20^{\circ} \mathrm{C}$ until analyzed.

For ashing of the samples, $50-150 \mathrm{mg}$ of the hair and nail samples was placed in a Teflon digestion vessel (capacity $23 \mathrm{ml}$, Uniseal Decomposition Vessels, Ltd., Haifa, Israel) and heated at $140^{\circ} \mathrm{C}$ for $3 \mathrm{~h}$ in the presence of a $\mathrm{HNO}_{3}(2.4 \mathrm{ml})-\mathrm{HClO}_{4}(0.6$ $\mathrm{ml})$ mixture. Three $\mathrm{ml}$ of the urine was heated in the presence of a $\mathrm{HNO}_{3}(0.4 \mathrm{ml})-\mathrm{HClO}_{4}(0.1 \mathrm{ml})$ mixture in the same manner as the hair and nails. The final digest was made up to $10 \mathrm{ml}$ for the hair and the nails, and $6 \mathrm{ml}$ for the urine with redistilled water in a screw-cap polypropylene tube.

The concentrations of Ge were measured by a standard addition analysis method using flameless atomic absorption spectrophotometry. The digest was further diluted 3-8 times in the final determination. Diammonium hydrogenphosphate $\left(\mathrm{NH}_{4}\right)_{2} \mathrm{HPO}_{4}(1-2 \%$ as final concentration) was used as the matrix modifier (9). A Hitachi assembly employed for automated determination was composed of a polarized Zeeman atomic absorption spectrophotometer (model Z-8000), an optical temperature controller (model 180-0341), and an autosampler (model 190-9210). The graphite furnace was of the tube type (model 180-7400), and heated at $30-105^{\circ} \mathrm{C}$ for $15 \mathrm{~s}$ and at $105-120^{\circ} \mathrm{C}$ for $5 \mathrm{~s}$ for drying (ramp mode), at $250-500^{\circ} \mathrm{C}$ for
$3 \mathrm{~s}$ and at $500-500^{\circ} \mathrm{C}$ for $2 \mathrm{~s}$ for ashing (ramp mode), and at $2600^{\circ} \mathrm{C}$ for $4 \mathrm{~s}$ for atomizing. A Ge hollow cathode lamp (current supply at $12.5 \mathrm{~mA}$ ) was used at $265.2 \mathrm{~nm}$.

Reagents, including the standard solution of $\mathrm{Ge}$ and mineral acids for ashing (trace element analysis grade) and diammonium hydrogenphosphate, were purchased from Wako Pure Chemicals (Osaka, Japan). Before use, vessels, plastic tubes and bottles (for wet ashing and storage) were washed with detergent and acid, and then rinsed with redistilled water to minimize metal contamination.

\section{RESULTS}

The concentrations of $\mathrm{Ge}$ in the hair and nails of each patient are summarized in Table 1 . The Ge concentrations were extremely high in cases 1 and 2 , in which the total doses were higher than those in other cases and the intake had been stopped a few months before. On the other hand, the concentrations in cases 4 and 5 , in which the intake was stopped more than a yr before, were almost normal or only slightly elevated.

In cases 1 and 2, high concentrations of $\mathrm{Ge}$ remained in all parts of the hair, as analyzed at every $2.5 \mathrm{~cm}$ from the proximal end along the hair shaft. The concentrations of 6 segments of hair length of about $15 \mathrm{~cm}$ in case 1 were $400.2,166.3,199.7$, $121.2,172.3$ and $265.5 \mu \mathrm{g} / \mathrm{g}$, and in case 2 , those

Table 1. Concentration of germanium in each case.

\begin{tabular}{|c|c|c|c|c|}
\hline \multirow[t]{2}{*}{ Case } & \multirow{2}{*}{$\begin{array}{l}\text { Total dose } \\
\text { (g) }\end{array}$} & \multirow{2}{*}{$\begin{array}{l}\text { Duration of } \\
\text { wash out } \\
\text { (months) }\end{array}$} & \multicolumn{2}{|c|}{ Concentration of germanium } \\
\hline & & & hair $(\mu \mathrm{g} / \mathrm{g})$ & finger nail $(\mu \mathrm{g} / \mathrm{g})$ \\
\hline 1 & 40 & 3 & 192.3 & \\
\hline 2 & 55 & 2 & 171.8 & 18.0 \\
\hline 3 & 20 & 3 & 1.6 & 26.3 \\
\hline 4 & unknown & 20 & 0.1 & $\begin{array}{l}0.2 \\
\left(0.8^{*}\right)\end{array}$ \\
\hline 5 & 16 & 19 & 0.1 & 0.4 \\
\hline \multicolumn{3}{|c|}{ normal person } & 0.1 & $\mathrm{nd}$ \\
\hline
\end{tabular}

Duration of wash out: the time period after the cessation of germanium intake

* toe nail; $\mathrm{n}$ d, not detectable 
Table 2. Serial concentration of germanium in case 2 .

\begin{tabular}{cccc}
\hline \multirow{2}{*}{$\begin{array}{l}\text { Duration of } \\
\text { wash out } \\
\text { (months) }\end{array}$} & \multicolumn{3}{c}{ Concentration of germanium } \\
\cline { 2 - 4 } & $\begin{array}{c}\text { hair } \\
(\mu \mathrm{g} / \mathrm{g})\end{array}$ & $\begin{array}{c}\text { finger nail } \\
(\mu \mathrm{g} / \mathrm{g})\end{array}$ & $\begin{array}{c}\text { urine } \\
(\mu \mathrm{g} / \mathrm{g} . \mathrm{Cr})\end{array}$ \\
\hline 2 & 171.8 & 18.0 & 1,510 \\
4 & 199.2 & & 369 \\
5 & & 30.4 & \\
6 & 161.1 & 23.6 & 381 \\
9 & & & \\
10 & 11.3 & 2.0 & 78 \\
\hline normal person & 0.1 & $\mathrm{nd}$ & \\
\hline
\end{tabular}

Duration of wash out: the time period after the cessation of germanium intake $\mathrm{n} \mathrm{d}$, not detectable

of 3 segments of hair length of about $7.5 \mathrm{~cm}$ were $163.0,175.4$ and $175.4 \mu \mathrm{g} / \mathrm{g}$.

The serial Ge concentrations in the hair, nails and urine were investigated in case 2 (Table 2). The levels in each sample gradually decreased, but were still high ten months after the patient stopped the Ge intake.

\section{DISCUSSION}

The toxicity of organic Ge compounds such as spirogermanium and carboxyethylgermanium sesquioxide, which are new anti-cancer drugs, have been evaluated (10-14). Whereas the former has neurotoxicity (10-12) and pulmonary toxicity (15), the latter has extremely low toxicity and both drugs have no nephrotoxicity. However, recently several cases of renal failure presumably due to Ge toxicity have been reported in Japan (2-5).

The renal function was deteriorated without proteinuria or hematuria in all of the present cases. Histological examination of the kidneys in two patients showed widespread tubular degeneration and diffuse interstitial fibrosis with minor glomerular abnormalities. These findings are similar to those in the previously reported cases (3-5). Most of the patients reported as Ge-induced nephropathy, including our patients, have taken $\mathrm{Ge}$ preparations primarily containing an inorganic compound of germanium dioxide $\left(\mathrm{GeO}_{2}\right)$. Matsusaka et al (4) have proposed, on the basis of animal experiments, that $\mathrm{GeO}_{2}$ can directly induce renal tubular damage by its toxic effect. The clinical and histological findings of the kidneys in the present cases support the suggestion of previous reports (4, 5) that inorganic $\mathrm{Ge}$, perhaps $\mathrm{GeO}_{2}$, may be nephrotoxic in humans.

Most of the patients had gastrointestinal symptoms such as nausea, vomiting, anorexia and weight loss. These symptoms were more severe in cases 1 and 2, in which doses of Ge preparations were higher than those of other cases. Routine gastrointestinal examination revealed no abnormalities in either case. The result of intestinal transit by radio-opaque markers examined in case 2 suggests that long-term Ge intake may impair gastrointestinal motor activity, although no exact mechanism is known.

Three patients had normochromic normocytic anemia. The anemia in these patients seems to be caused by both renal failure and malnutrition. Although the histological examination of bone marrow in two patients showed hypoplasia, the direct effect of Ge toxicity on bone marrow remains to be studied.

Peripheral neuropathy and myopathy were observed in case 2 . These symptoms have been noted as complications of Ge-induced nephropathy in previous reports $(3,4)$. The peripheral neuropathy in this case was more severe than the common type of uremic neuropathy. Spirogermanium has been reported to induce transient neurological symptoms including paresthesia $(10,12)$. Nakano et al have reported that myopathy develops in rats given $\mathrm{GeO}_{2}$ orally (16). Therefore, we presume that Ge intake directly induced the peripheral neuropathy and myopathy in this case.

In general, Ge does not accumulate in the human body, in spite of its ubiquitous presence in the soil, plants and food (17). However, a considerable amount of Ge could be detected in the hair or nails of our five patients. The Ge concentrations of the nails were high even in the patients (cases 4 and 5) who stopped taking Ge preparations more than a yr before, as compared with a normal person. The concentration of each sample in case 2 was 
still high ten months after stopping the intake. These results indicate that $\mathrm{Ge}$ is stored in the body for a long time, when a large amount of inorganic $\mathrm{Ge}$ compound is taken. The renal dysfunction and extrarenal symptoms were more serious in the two patients (cases 1 and 2), who took higher doses of Ge than other patients. This suggests that both the renal damage and the various extrarenal manifestations may be caused by Ge toxicity. Thus, it should be noted that the excessive abuse of inorganic Ge compounds can induce not only severe renal damage, but also various and sometimes serious extrarenal manifestations such as frequent vomiting, weight loss, peripheral neuropathy and myopathy.

This study is supported by research grants (progressive renal lesions) from the Intractable Disease Division, Public Health Bureau, Ministry of Health and Welfare, Japan, and grants from the Miyagi Prefecture Kidney Association, Japan

\section{REFERENCES}

1) Schroeder HA, Balassa JJ. Abnormal trace metals in man: germanium. J Chronic Dis 20: 211, 1967.

2) Nagata $N$, Yoneyama $T$, Yanagida $K$, et al. Accumulation of germanium in the tissues of a long-term user of germanium preparation died of acute renal failure. J Toxicol Sci 10: 333, 1985.

3) Okuda S, Kiyama S, Oh Y, et al. Persistent renal dysfunction induced by chronic intake of germaniumcontaining compounds. Curr Ther Res Clin Exp 41: 265, 1987.

4) Matsusaka T, Fujii M, Nakano T, et al. Germaniuminduced nephropathy: report of two cases and review of the literature. Clin Nephrol 30: 341, 1988.

5) Okada K, Okagawa K, Kawakami K, et al. Renal failure caused by long-term use of a germanium preparation as an elixir. Clin Nephrol 31: 219, 1989.
6) Satake K, Hongo M, Ujiie H, Okuno Y, Goto Y. The effect of cisapride on intestinal transit. Jpn J Smooth Muscle Res 24: 55, 1988.

7) International Atomic Energy Agency. Report of the advisory group on the application of nuclear methods in environmental research, Internal document, IAEA, Vienna, 1976.

8) Morita M, Saito H. Hair analysis by ICP-AES and its application to the population at Kosaka, Akita. Res Rep Natl Inst Environ Stud Jpn 84: 73, 1985.

9) Carnrick GR, Bamett WB. Determination of germanium by zeeman atomic absorption spectrophotometry. At Spectrosc 5: 213, 1984.

10) Schein PS, Slavik M, Smythe T, et al. Phase I clinical trial of spirogermanium. Cancer Treat Rep 64: 1051, 1980.

11) Budman DR, Schulman $P$, Vinciguerra $V$, Degnan $T J$. Phase I trial of spirogermanium given by infusion in a multiple-dose schedule. Cancer Treat Rep 66: 173, 1982.

12) Vogelzang NJ, Gesme DH, Kennedy BJ. A phase II study of spirogermanium in advanced human malignancy. Am J Clin Oncol 8: 341, 1985.

13) Sato $H$, Iwaguchi $T$. Antitumor effect of a novel organogermanium compound, Ge-132. Jap J Cancer Chemother 6: 79, 1979.

14) Miyao K, Onishi T, Asai K, Tomizawa S, Suzuki F. Toxicology and phase I studies on a novel organogermanium compound, Ge-132. Proc 11th Int Congr Chemother 1980, p.1527.

15) Dixon C, Hagemeister F, Legha S, Bodey G. Pulmonary toxicity associated with spirogermanium. Cancer Treat Rep 68: 907, 1984.

16) Nakano T, Fujii M, Terai T, Matsusaka T, Kimura M, Toyomasu T. An ultrastructural study of rats treated with germanium. J Clin Electron Microscopy 20: 850, 1987.

17) Venugopal B, Luckey TD. Metal toxicity in mammals-2. Chemical toxicity of metal and metalloids. Plenum Press, New York, 1978, p.175. 